\title{
Transcatheter embolization in pediatric blunt renal trauma: Case report and review of the literature
}

\author{
İbrahim Kartal, M.D., ${ }^{1}$ Hasan Ali Durmaz, M.D., ${ }^{2}$ ๑ Sanem Güler Çimen, M.D., ${ }^{3}$ \\ Sertaç Çimen, M.D., 1 (D) Hamit Ersoy, M.D.'
}

\begin{abstract}
1'Department of Urology, Health Sciences University, Dışkapı Yıldırım Beyazıt Training and Research Hospital, Ankara-Turkey 2Department of Radiology, Health Sciences University, Dışkapı Yıldırım Beyazıt Training and Research Hospital, Ankara-Turkey ${ }^{3}$ Department of General Surgery, Health Sciences University, Dışkapı Yıldırım Beyazıt Training and Research Hospital, Ankara-Turkey
\end{abstract}

\begin{abstract}
This study aims to evaluate the clinical use and outcomes of transcatheter embolization in the setting of pediatric blunt renal trauma cases using an index case and review of the literature. Although the treatment method selection depends on the grade of the trauma and the hemodynamic status of the patient, conservative methods are considered initially in the setting of pediatric blunt renal trauma. Transcatheter embolization, which is a relatively conservative treatment option, is commonly utilized in adult blunt renal trauma patient population; however, experience in the pediatric population is scarce. A seven-year-old male patient was admitted due to grade IV renal injury secondary to blunt abdominal trauma. He was conservatively followed until -on the post-trauma day 15- he developed gross hematuria and an unstable hemodynamic status. A renal angiogram was performed, which revealed rightsided renal inferior segmental artery pseudoaneurysm and arterio-venous fistula. Subsequently, a transcatheter embolization was performed. There were no complications and no permanent renal injury. Review of the literature revealed that the success rate of transcatheter embolization is $\mathbf{8 9 . 4 7 \%}$ in the setting of pediatric blunt abdominal trauma-related renal injury regardless of the renal trauma grade. Four patients underwent nephrectomy due to a failed transcatheter embolization procedure. There are not any patients who suffered from embolization-related complications. These results suggest that transcatheter embolization can be safely performed in children with renal injuries due to blunt abdominal trauma with high success and low complication rates and preservation of renal function.
\end{abstract}

Keywords: Abdominal injuries; aneurysm; child; conservative treatment; kidney.

\section{INTRODUCTION}

Kidneys are injured in 10-20\% of pediatric blunt abdominal trauma cases. ${ }^{[I]}$ These renal injury cases do not usually require surgical interventions and the aim of the therapeutic approach is the preservation of renal function and being as minimally invasive as possible. ${ }^{[2]}$ However, the selection of best treatment option depends on the hemodynamic status of the patient and grade of the renal injury.

The scale reported by the American Association for the Surgery of Trauma (AAST) is utilized for grading renal injuries. ${ }^{[3]}$ Although higher AAST grades are more likely to necessitate surgical treatments, even in the setting of highgrade renal injuries, conservative and/or minimally invasive treatment methods are considered first. ${ }^{[4,5]}$ Transcatheter angioembolization (TAE), which is one of the minimally invasive treatment methods, is performed in case of renal parenchymal lacerations, pseudoaneurysms and arteriovenous fistulas. In this study, we present a case of a renal injury that arises from a pediatric blunt abdominal trauma that later developed pseudoaneurysm and arteriovenous fistula, which were treated by TAE. In addition, we report our literature review results regarding the experience with TAE in the setting of pediatric blunt abdominal trauma-related renal injuries.

Cite this article as: Kartal İ, Durmaz HA, Çimen SG, Çimen S, Ersoy H. Transcatheter embolization in pediatric blunt renal trauma: Case report and review of the literature. Ulus Travma Acil Cerrahi Derg 2020;26:475-481.

Address for correspondence: İbrahim Kartal, M.D.

Sağlık Bilimleri Üniversitesi, Dışkapı Yıldırım Beyazıt Eğitim ve Araştıma Hastanesi, Üroloji Kliniği, Ankara, Turkey

Tel: +90 312 - 5962000 E-mail: ibrahimguvenkartal@gmail.com 


\section{CASE REPORT}

A seven-year-old male patient presented to the emergency department 50 minutes after falling off a building. He was hemodynamically stable, conscious and complaining about right-sided flank pain. His past medical and surgical history was unremarkable. He did not have gross hematuria. Physical examination revealed ecchymosis of the right flank region. Complete blood count revealed a hemoglobin level of $14.4 \mathrm{~g} /$ dl. Ultrasonography showed an inferolateral parenchymal laceration in the right kidney accompanied by a 5 -cm hematoma. This injury was accepted as AAST grade IV renal trauma. The patient was admitted and conservatively followed for one week. He did not have gross hematuria, hemoglobin decline or any hemodynamic problems during this admission period. One week after his discharge from the hospital, he presented to the emergency department with the complaint of macroscopic hematuria. Physical examination revealed rightsided costovertebral tenderness. His hemoglobin level was measured as $8.5 \mathrm{~g} / \mathrm{dl}$. Since he had a previously known right renal parenchymal laceration and hematoma, a renal Doppler ultrasound and a computerized tomography scan were performed. These investigations showed that the hematoma enlarged to $9 \mathrm{~cm}$ and there was a $15 \times 12 \mathrm{~mm}$ right renal inferior segmental artery pseudoaneurysm associated with an arteriovenous fistula. Renal angiogram performed after transfusion of two units of packed red blood cells confirmed the pseudoaneurysm and arteriovenous fistula (Fig. Ia). During this procedure, the right renal inferior segmental artery was selectively catheterized via a $2.4 \mathrm{~F}$ microcatheter (Progreat $^{\circledR}$, Terumo Medical Corporation, Somerset, New Jersey) and this artery was embolized by 14 various sized detachable coils (Azur ${ }^{\circledast}$, Terumo Medical Corporation, Somerset,
New Jersey). The control renal angiogram did not reveal the filling of the pseudoaneurysm and blood flow through the arteriovenous fistula (Fig. Ib). The patient was followed as an inpatient for five days after the intervention, and he was discharged since there were no hemodynamic problems and no hemoglobin decline during this period. Furthermore, no pseudoaneurysm or arteriovenous fistula was detected in the control of renal Doppler ultrasonography. Follow-up evaluation at the sixth month of follow-up included a dimercaptosuccinic acid (DMSA) nuclear renal scan, which showed an area of diminished perfusion, a finding consistent with the embolization of right renal inferior segmental artery. However, the whole right kidney was very well perfused otherwise. The split function of the right kidney was calculated as $35 \%$. Similar findings were detected in the I-year follow-up visit. The patient is currently on an annual follow-up schedule. Patient's consent was obtained for this study.

\section{DISCUSSION}

Trauma is the leading cause of death in children older than one year. ${ }^{[6]}$ In children, kidneys are relatively larger, and they are more mobile. They are located at a lower level in the retroperitoneum; therefore, they are protected less by the ribs when compared with adults. In addition, there is less perinephric fat compared with adult kidneys. As a result, the risk of renal injury is higher in the pediatric population in the setting of blunt abdominal trauma. ${ }^{[7]}$

Management of pediatric blunt renal trauma depends on the hemodynamic status of the patient and the grade of renal injury. Most renal injuries can be followed conservatively. Surgical treatment is needed in approximately $5-10 \%$ of these
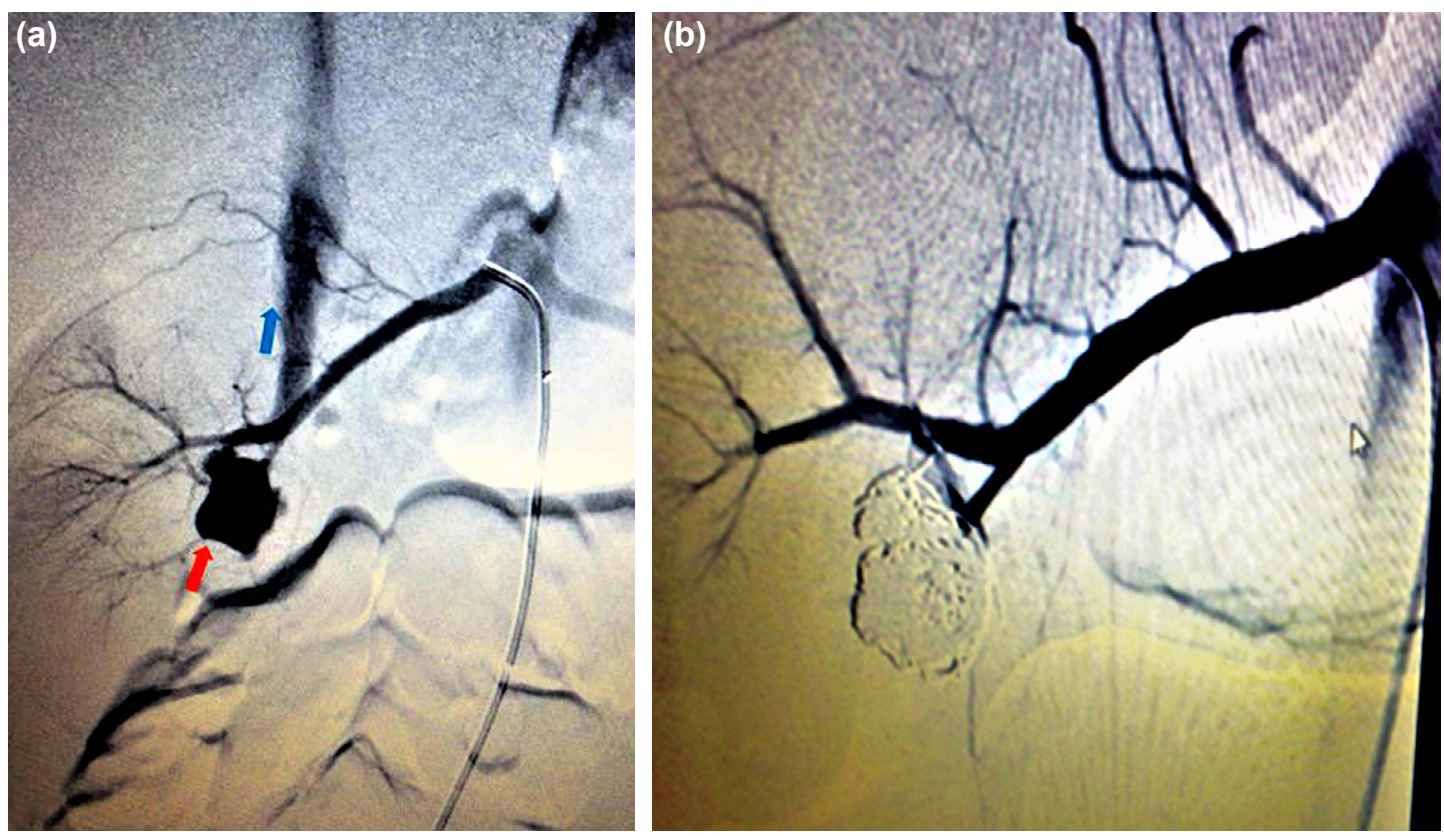

Figure 1. (a) Renal angiogram demonstrating the pseudoaneurysm at the right renal inferior segmental artery (red arrow) and arteriovenous fistula (blue arrow). (b) Post-embolization control renal angiogram image. 


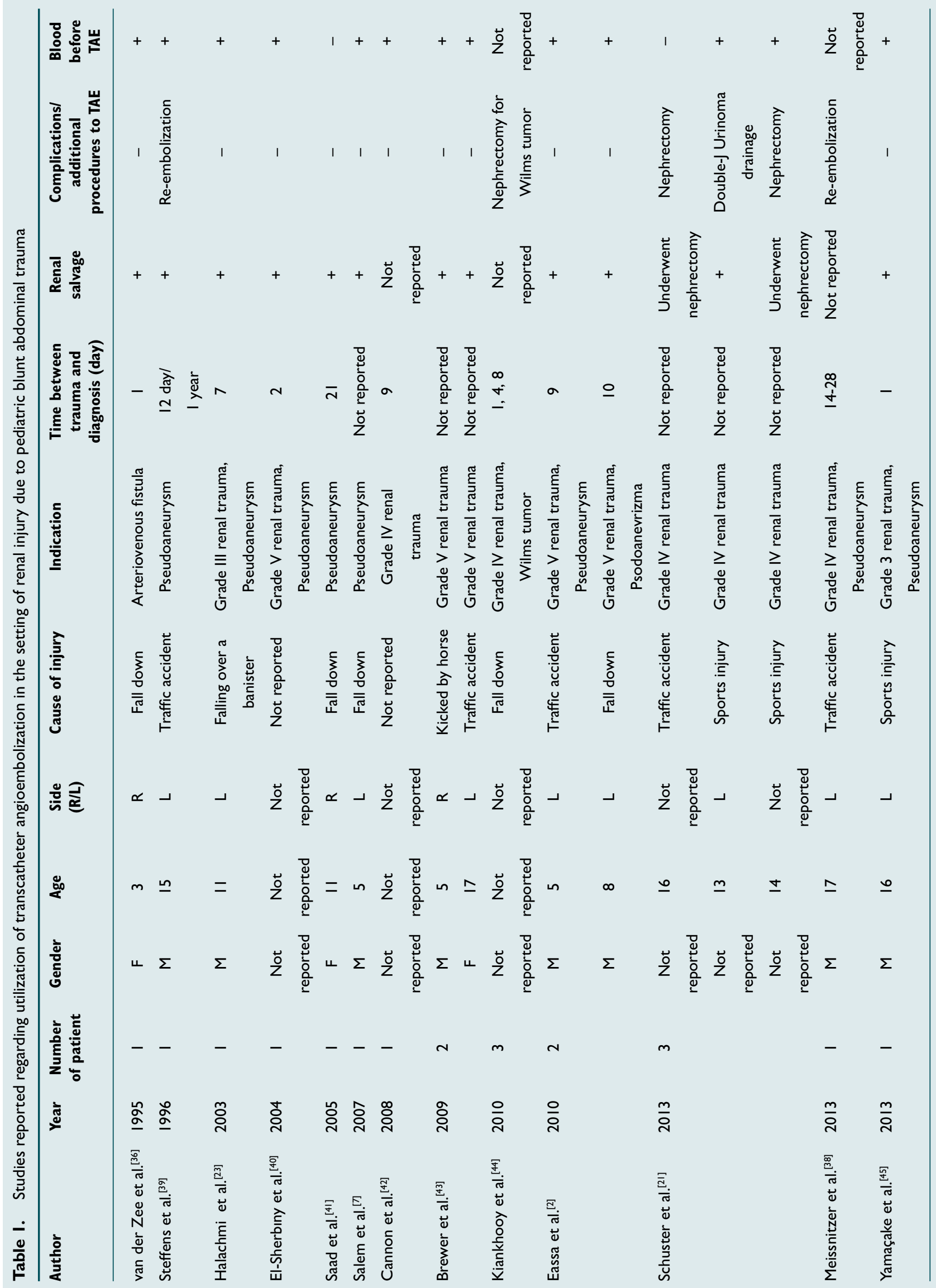




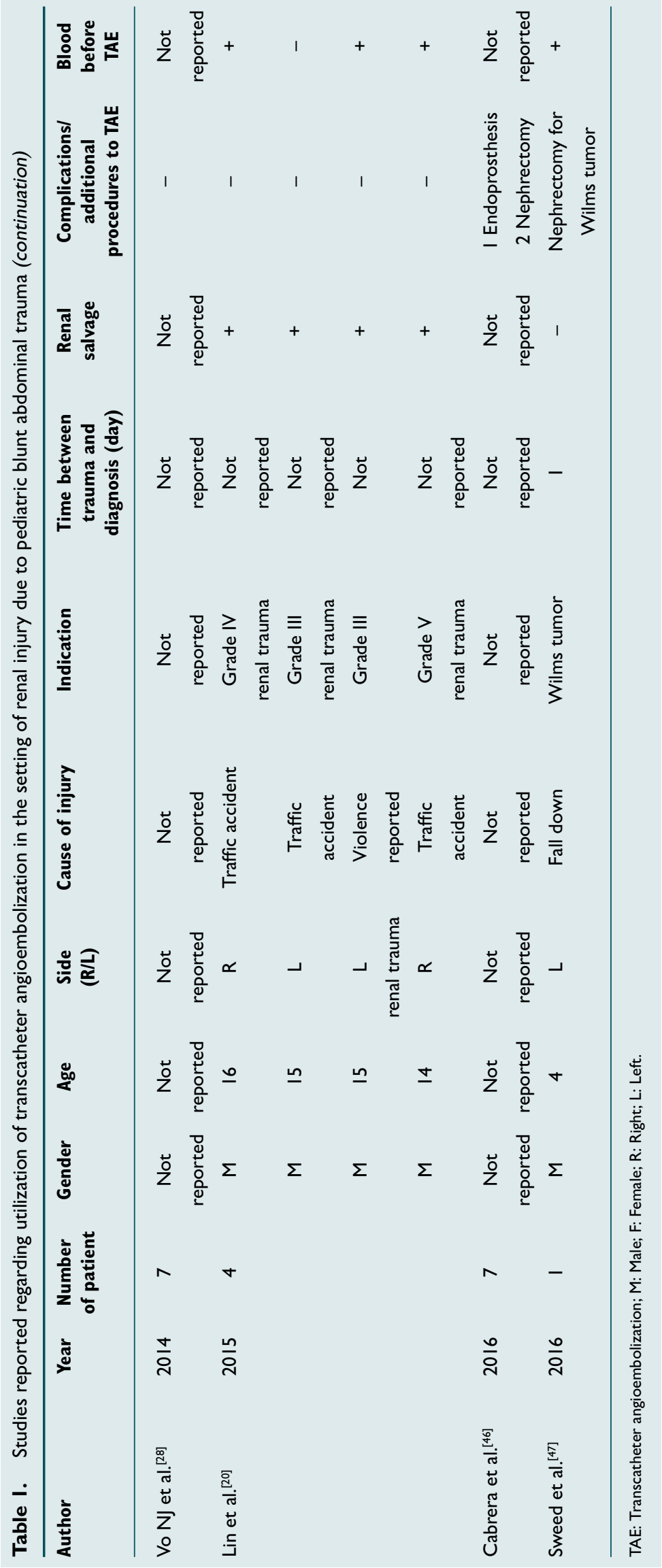

cases, and this rate is declining day by day due to increasing the availability of minimally invasive treatment procedures ${ }^{[8]}$ Surgical treatment is usually preferred in hemodynamically unstable patients or patients with renal vascular pedicle injury, ureteropelvic junction injury or in the setting of failed conservative treatment. Nephrectomy is performed in $60-65 \%$ of grade IV or $V$ renal injuries treated surgically. ${ }^{[9]}$ On the other hand, in children with blunt renal trauma, the success rates of conservative treatment are higher when compared with adults. ${ }^{[10]}$ Even in case of grade $\mathrm{V}$ renal traumas, an $\sim 80 \%$ conservative treatment success ratio was reported. ${ }^{[1-13]}$

The utilization of imaging studies is critical for diagnosis and grading of renal injury. ${ }^{[14]}$ In children with blunt abdominal trauma, imaging studies should be performed in the case of hematuria, abdominal skin ecchymosis, abdominal pain, distention and significant hemoglobin drop. Ultrasonography is the preferred initial imaging modality despite its low efficacy in grading renal injury and its operator-dependence. ${ }^{[15]}$ However, spiral computerized tomography, including non-contrast phase, arterial contrast phase and late phases is more widely used in pediatric cases since it can visualize the renal parenchyma, vascular structures and collecting systems and it can simultaneously view the other abdominal organs. ${ }^{[16]}$ Consequently, computerized tomography has been recommended as the gold standard imaging modality for children presenting with blunt renal trauma. ${ }^{[1]]}$ On the other hand, ultrasonography is suggested for periodic follow-up imaging as per 'as low as reasonably achievable' (ALARA) principle in order to reduce radiationrelated risks since children are more sensitive to radiation when compared with adults. ${ }^{[17,18]} \mathrm{Com}-$ puterized tomography is preferred during followup only when ultrasonographic imaging reveals any suspicious findings.

It has been reported that vascular injuries in the setting of blunt renal traumas can be treated effectively by TAE. ${ }^{[2,19-26]}$ This procedure can be performed in children whose hemodynamic status is either stable or nearly stable and who have active bleeding due to renal parenchymal bleeding, contrast extravasation or perirenal hematoma detected in computerized tomography scan. In addition, it can be utilized in patients with late bleeding following conservative treatment, arterial pseudoaneurysm or arteriovenous fistula.

The response of a child to acute bleeding differs from an adult's response; mental state variations, 
hypotension, signs of decreased peripheral perfusion and respiratory changes all occur at a later post-trauma phase compared to adults. ${ }^{[27]}$ Thus, tachycardia without accompanying hypotension can be the first sign of internal hemorrhage. This is significant because pre-TAE blood transfusion rates inversely correlate with the efficacy of TAE. ${ }^{[28,29]}$

Although renal artery pseudoaneurysm is mostly iatrogenic, it can rarely be due to blunt abdominal trauma. ${ }^{[30]}$ It may cause abdominal tenderness, ecchymosis and/or mass with pulsation at the flank, hematuria, nausea and shock. Rarely, a renal artery pseudoaneurysm may spontaneously get thrombosed and remain asymptomatic for years before it is diagnosed. ${ }^{[3]]}$ Usually, the time interval between the blunt abdominal trauma leading to renal artery pseudoaneurysm and the bleeding caused by it (i.e., secondary renal hemorrhage) is in the range of 2-36 days. ${ }^{[32]}$ Our literature review showed that, in children, the time interval between the trauma and diagnosis of renal artery pseudoaneurysm varies from one day to one year (Table I). Regardless of the time of diagnosis, it can be either conservatively followed or treated by either TAE or open surgery, depending on the clinical status of the patient and the location of the pseudoaneurysm. ${ }^{[33]}$

Rarely, an acquired arteriovenous fistula may occur between the renal arterial and venous systems. ${ }^{[34]}$ These fistulas are usually formed at the right kidney. Although the most common cause is penetrating trauma, these fistulas may also occur as a result of blunt abdominal trauma. ${ }^{[35]}$ However, these patients are usually underdiagnosed during the initial assessment. They may present with renovascular hypertension and/ or congestive heart failure years after the trauma. Kuy et al. ${ }^{[35]}$ and van der Zee et al. ${ }^{[36]}$ reported that renal arteriovenous fistulas, which were previously repaired by open surgery, could be treated by TAE in children with the benefit of preserving renal function.

The complication profile of TAE is similar between children and adults; however, complication rates are lower in the former group. ${ }^{[2]}$ Formation of hematoma in the arterial access site, arterial injury due to catheter or guidewire, contrast nephropathy, renal ischemia (i.e., target organ ischemia) and embolization of the non-targeted organ are the potential complications of TAE in children. ${ }^{[37]}$ Renal artery dissection is detected in $7.5 \%$ of the adult patient population as a complication of TAE; this complication has never been encountered in children.

Complications and/or failure of TAE can occasionally necessitate additional interventions. Our literature review revealed that four patients underwent nephrectomy due to failure. One patient who experienced urinary extravasation needed double J stent and urinoma drainage catheter insertion. In another patient, endoprosthesis placement was performed for renal revascularization. Two patients who were evaluated due to blunt renal trauma following falling off a height were inci- dentally diagnosed by Wilms tumor. Bleeding was controlled by TAE in both cases; however, these patients both underwent nephrectomy afterward under elective circumstances. Two patients reported in the literature required repeat of TAE procedure due to failure at the first attempt; second attempts were successful in both cases (Table I). ${ }^{[38]}$

Experience gained in the adult patient population shedding light on the TAE applications in pediatric patients and assisted in achieving low complication rates. In addition -for maximum preservation of renal function- selective and even super-selective TAE applications have emerged. ${ }^{[23]}$ As a result, our literature review revealed that -in total- 38 pediatric patients underwent TAE due to blunt renal trauma, and the overall success rate was $\sim 89.5 \%$. Of note, this review also exposed that TAE not only helped in the preservation of the function of the ipsilateral kidney, but it also did not have any impact on the long-term functional status of the contralateral kidney. ${ }^{[40-47]}$

\section{Conclusion}

The risk of exposure to blunt abdominal trauma-related renal injury is significantly higher in children than adults. In hemodynamically stable patients, conservative or non-surgical treatment methods are preferred since they eliminate the potential risks of emergent surgery, preserve the functionality of the target organ and provide favorable long-term results. In our index case, we treated both the renal pseudoaneurysm and arteriovenous fistula, which caused posttrauma renal bleeding successfully by TAE. This patient did not experience any complications or renal function decline during follow-up. As such, our literature review showed that -although the experience in children is not extensive- TAE can be safely and successfully performed in the pediatric blunt renal trauma population. No long-term complications of TAE were reported except for the cases which required nephrectomy following a failed TAE. Of note, 'TAE failure' itself is not the reason for nephrectomy in these cases.

Informed Consent: Written informed consent was obtained from the parents of the patient for the publication of the case report and the accompanying images.

Peer-review: Internally peer-reviewed.

Authorship Contributions: Concept: I..K., H.A.D.; Design: I.K., H.A.D; Supervision: S.G.Ç., S.Ç.; Materials: I.K., H.A.D., H.E.; Data: I.K., H.A.D.; Analysis: I.K.; Literature search: I.K., S.G.Ç.; Writing: I.K., S.Ç.; Critical revision: I.K., S.G.Ç., H.E.

Conflict of Interest: None declared.

Financial Disclosure: The authors declared that this study has received no financial support.

\section{REFERENCES}

1. Meng MV, Brandes SB, McAninch JW. Renal trauma: indications and techniques for surgical exploration. World J Urol 1999;17:71-7. [CrossRef]

2. Eassa W, El-Ghar MA, Jednak R, El-Sherbiny M. Nonoperative manage- 
ment of grade 5 renal injury in children: does it have a place?. Eur Urol 2010;57:154-61. [CrossRef]

3. Tinkoff G, Esposito TJ, Reed J, Kilgo P, Fildes J, Pasquale M, et al. American Association for the Surgery of Trauma Organ Injury Scale I: spleen, liver, and kidney, validation based on the National Trauma Data Bank. J Am Coll Surg 2008;207:646-55. [CrossRef]

4. Ierardi AM, Duka E, Lucchina N, Floridi C, De Martino A, Donat D, et al. The role of interventional radiology in abdominopelvic trauma. Br J Radiol 2016;89:20150866. [CrossRef]

5. Ramaswamy RS, Darcy MD. Arterial Embolization for the Treatment of Renal Masses and Traumatic Renal Injuries. Tech Vasc Interv Radiol 2016;19:203-10. [CrossRef]

6. Mendelson KG, Fallat ME. Pediatric injuries: prevention to resolution. Surg Clin North Am 2007;87:207-viii. [CrossRef]

7. Salem HK, Morsi HA, Zakaria A. Management of high-grade renal injuries in children after blunt abdominal trauma: experience of 40 cases. J Pediatr Urol 2007;3:223-9. [CrossRef]

8. Danuser H, Wille S, Zöscher G, Studer U. How to treat blunt kidney ruptures: primary open surgery or conservative treatment with deferred surgery when necessary?. Eur Urol 2001;39:9-14. [CrossRef]

9. Jacobs MA, Hotaling JM, Mueller BA, Koyle M, Rivara F, Voelzke BB. Conservative management vs early surgery for high grade pediatric renal trauma-do nephrectomy rates differ?.J Urol 2012;187:1817-22. [CrossRef]

10. Dent D, Alsabrook G, Erickson BA, Myers J, Wholey M, Stewart R, et al. Blunt splenic injuries: high nonoperative management rate can be achieved with selective embolization. J Trauma 2004;56:1063-7. [CrossRef]

11. Buckley JC, McAninch JW. Pediatric renal injuries: management guidelines from a 25-year experience. J Urol 2004;172:687-90. [CrossRef]

12. Altman AL, Haas C, Dinchman KH, Spirnak JP. Selective nonoperative management of blunt grade 5 renal injury. J Urol 2000;164:27-31.

13. Henderson CG, Sedberry-Ross S, Pickard R, Bulas DI, Duffy BJ, Tsung $D$, et al. Management of high grade renal trauma: 20-year experience at a pediatric level I trauma center. J Urol 2007;178:246-50. [CrossRef]

14. Bryk DJ, Zhao LC. Guideline of guidelines: a review of urological trauma guidelines. BJU Int 2016;117:226-34. [CrossRef]

15. Sivit CJ. Imaging children with abdominal trauma. AJR Am J Roentgenol 2009;192:1179-89. [CrossRef]

16. Becker CD, Mentha G, Schmidlin F, Terrier F. Blunt abdominal trauma in adults: role of $\mathrm{CT}$ in the diagnosis and management of visceral injuries. Part 2: Gastrointestinal tract and retroperitoneal organs. Eur Radiol 1998;8:772-80. [CrossRef]

17. Eeg KR, Khoury AE, Halachmi S, Braga LH, Farhat WA, Bägli DJ, et al. Single center experience with application of the ALARA concept to serial imaging studies after blunt renal trauma in children--is ultrasound enough? J Urol 2009;181:1834-40. [CrossRef]

18. Brenner D, Elliston C, Hall E, Berdon W. Estimated risks of radiation-induced fatal cancer from pediatric CT. AJR Am J Roentgenol 2001;176:289-96. [CrossRef]

19. Dinkel HP, Danuser H, Triller J. Blunt renal trauma: minimally invasive management with microcatheter embolization experience in nine patients. Radiology 2002;223:723-30. [CrossRef]

20. Lin WC, Lin CH. The role of interventional radiology for pediatric blunt renal trauma. Ital J Pediatr 2015;41:76. [CrossRef]

21. Schuster T, Leissner G. Selective angioembolization in blunt solid organ injury in children and adolescents: review of recent literature and own experiences. Eur J Pediatr Surg 2013;23:454-63. [CrossRef]

22. Angus LD, Tachmes L, Kahn S, Gulmi F, Gintautas J, Shaftan GW. Surgical management of pediatric renal trauma: an urban experience. Am Surg 1993;59:388-94.
23. Halachmi S, Chait P, Hodapp J, Bgli DG, McLorie GA, Khoury AE, et al. Renal pseudoaneurysm after blunt renal trauma in a pediatric patient: management by angiographic embolization. Urology 2003;61:224.

24. van der Vlies CH, Olthof DC, van Delden OM, Ponsen KJ, de la Rosette $\mathrm{JJ}$, de Reijke TM, et al. Management of blunt renal injury in a level 1 trauma centre in view of the European guidelines. Injury 2012;43:1816-20.

25. Breyer BN, McAninch JW, Elliott SP, Master VA. Minimally invasive endovascular techniques to treat acute renal hemorrhage. J Urol 2008;179:2248-53. [CrossRef]

26. Puapong D, Brown CV, Katz M, Kasotakis G, Applebaum H, Salim A, et al. Angiography and the pediatric trauma patient: a 10 -year review. J Pediatr Surg 2006;41:1859-63. [CrossRef]

27. Hamner CE, Groner JI, Caniano DA, Hayes JR, Kenney BD. Blunt intraabdominal arterial injury in pediatric trauma patients: injury distribution and markers of outcome. J Pediatr Surg 2008;43:916-23. [CrossRef]

28. Vo NJ, Althoen M, Hippe DS, Prabhu SJ, Valji K, Padia SA. Pediatric abdominal and pelvic trauma: safety and efficacy of arterial embolization. J Vasc Interv Radiol 2014;25:215-20. [CrossRef]

29. Dente CJ, Shaz BH, Nicholas JM, Harris RS, Wyrzykowski AD, Patel S, et al. Improvements in early mortality and coagulopathy are sustained better in patients with blunt trauma after institution of a massive transfusion protocol in a civilian level I trauma center. J Trauma 2009;66:1616-24.

30. Farrell TM, Sutton JE, Burchard KW. Renal artery pseudoaneurysm: a cause of delayed hematuria in blunt trauma. J Trauma 1996;41:1067-8.

31. Lee RS, Porter JR. Traumatic renal artery pseudoaneurysm: diagnosis and management techniques. J Trauma 2003;55:972-8. [CrossRef]

32. Heyns CF, de Klerk DP, de Kock ML. Stab wounds associated with hematuria--a review of 67 cases. J Urol 1983;130:228-31. [CrossRef]

33. Teigen CL, Venbrux AC, Quinlan DM, Jeffs RD. Late massive hematuria as a complication of conservative management of blunt renal trauma in children. J Urol 1992;147:1333-6. [CrossRef]

34. Wright JL, Porter JR. Renal artery pseudoaneurysm after laparoscopic partial nephrectomy. Urology 2005;66:1109. [CrossRef]

35. Kuy S, Rossi PJ, Seabrook GR, Brown KR, Lewis BD, Rilling WS, et al. Endovascular management of a traumatic renal-caval arteriovenous fistula in a pediatric patient. Ann Vasc Surg 2014;28:1031.e1-5. [CrossRef]

36. van der Zee JA, van den Hoek J, Weerts JG. Traumatic renal arteriovenous fistula in a 3-year-old girl, successfully treated by percutaneous transluminal embolization. J Pediatr Surg 1995;30:1513-14. [CrossRef]

37. Corr P, Hacking G. Embolization in traumatic intrarenal vascular injuries. Clin Radiol 1991;43:262-4. [CrossRef]

38. Meissnitzer T, Hruby S, Janetschek G, Meissnitzer MW. Recurrence of a Delayed-Onset Posttraumatic Renal Pseudoaneurysm after Initially Successful Transarterial Embolization. Urol Int 2017;98:245-8. [CrossRef]

39. Steffens MG, Bode PJ, Lycklama à Nijeholt AA, van Vugt AB. Selective embolization of pseudo-aneurysms of the renal artery after blunt abdominal injury in a patient with a single kidney. Injury 1996;27:219-20.

40. El-Sherbiny MT, Aboul-Ghar ME, Hafez AT, Hammad AA, Bazeed MA. Late renal functional and morphological evaluation after non-operative treatment of high-grade renal injuries in children. BJU Int 2004;93:1053-6.

41. Saad DF, Gow KW, Redd D, Rausbaum G, Wulkan ML. Renal artery pseudoaneurysm secondary to blunt trauma treated with microcoil embolization. J Pediatr Surg 2005;40:e65-7. [CrossRef]

42. Cannon GM Jr, Polsky EG, Smaldone MC, Gaines BA, Schneck FX, Bellinger MF, et al. Computerized tomography findings in pediatric renal trauma--indications for early intervention? J Urol 2008;179:1529-33.

43. Brewer ME Jr, Strnad BT, Daley BJ, Currier RP, Klein FA, Mobley JD, et al. Percutaneous embolization for the management of grade 5 renal trauma in hemodynamically unstable patients: initial experience. J Urol 
2009;181:1737-41. [CrossRef]

44. Kiankhooy A, Sartorelli KH, Vane DW, Bhave AD. Angiographic embolization is safe and effective therapy for blunt abdominal solid organ injury in children. J Trauma 2010;68:526-31. [CrossRef]

45. Yamaçake KG, Lucon M, Lucon AM, Mesquita JL, Srougi M. Renal artery pseudoaneurysm after blunt renal trauma: report on three cases and review of the literature. Sao Paulo Med J 2013;131:356-62. [CrossRef]
46. Bordón Cabrera E, Laín A, Gander R, Pérez Lafuente M, Díez Miranda I, Fontecha CG, et al. Vascular interventional radiology: a fundamental procedure for the management of paediatric trauma. [Article in Spanish] Cir Pediatr 2016;29:25-30.

47. Sweed Y, Singer-Jordan J, Papura S, Loberant N, Yulevich A. Angiographic Embolization in Pediatric Abdominal Trauma. Isr Med Assoc J 2016;18:665-8.

\section{OLGU SUNUMU - ÖZET}

\section{Pediatrik künt renal travmalarda transkateter embolizasyon: Olgu sunumu ve literatür derlemesi}

\section{Dr. İbrahim Kartal, ${ }^{1}$ Dr. Hasan Ali Durmaz, ${ }^{2}$ Dr. Sanem Güler Çimen, ${ }^{3}$ Dr. Sertaç Çimen, ${ }^{1}$ Dr. Hamit Ersoy ${ }^{1}$}

'Sağlık Bilimleri Üniversitesi, Dışkapı Yıldııım Beyazıt Eğitim ve Araştırma Hastanesi, Üroloji Kliniği, Ankara

${ }^{2}$ Sağıık Bilimleri Üniversitesi, Dışkapı Yıldırım Beyazıt Eğitim ve Araştırma Hastanesi, Radyoloji Kliniği, Ankara

${ }^{3}$ Sağlık Bilimleri Üniversitesi, Dışkapı Yıldııım Beyazıt Eğitim ve Araştırma Hastanesi, Genel Cerrahi Kliniği, Ankara

Bu yazıda, pediatrik olgularda künt abdominal travma sonucu gelişen renal yaralanmaların tedavisinde transkateter embolizasyon kullanımı ve sonuçları, bir olgu ve literatür eşliğinde değerlendirildi. Abdominal künt travma sonrası çocuklarda renal yaralanma gerçekleşmesi durumunda tedavi tercihi renal travmanın derecesine ve hastanın hemodinamisine bağlı olmakla birlikte, tedavide mümkün olduğunca non-operatif yöntemlerin kullanılması önerilmektedir. Transkateter embolizasyon kullanımı erişkinlerde renal yaralanmalarda pratikte yaygın olarak kullanılırken, çocuklarda kullanımı ile ilgili deneyim azdır. Yedi yaşında erkek hastada künt abdominal travma ve buna bağılı olarak gelişen grade IV renal yaralanma nedeniyle takibe alındı. Konservatif yöntemlerle takip edilen hastada travma sonrası 15. günde hematüri ve hemodinamide bozulma gerçekleşti. Renal anjiyografide; sağ inferior segmental arterde psödoanevrizma ve arteriyovenöz fistül saptandı. Hastaya transkateter embolizasyon başarılı şekilde uygulandı, herhangi bir komplikasyon olmadığı gibi renal hasarda görülmedi. Literatür değerlendirmesinde pediatrik künt abdominal travma sonrası renal yaralanama nedeniyle yapılan transkateter embolizasyonun renal yaralanma derecesine bakılmaksızın başarı oranı \%89.47'dir. Transkateter embolizasyon başarısızlığı nedeniyle dört hastada nefrektomi yapılmış, hiçbir hastada uzun dönemde komplikasyon gözlenmemiştir. Bu sonuçlar eşliğinde çocuklarda, künt abdominal travma sonrası renal yaralanmaların transkateter embolizasyon ile tedavisinde; düşük komplikasyon ile yüksek başarı bildirilmekte ve uzun dönemde renal fonksiyonun korunmasında da güvenilir bir yöntem olduğu anlaşılmaktadır. Anahtar sözcükler: Abdominal travma; anevrizma künt; böbrek; çocuk; konservatif tedavi.

Ulus Travma Acil Cerrahi Derg 2020;26(3):475-48I doi: 10.14744/tjtes.2019.93043 